\title{
Influence of palm oil factory wastes as coarse aggregate species for green lightweight concrete
}

\author{
Influencia de los residuos de fábrica de aceite de palma como especie de agregado grueso para \\ hormigón verde liviano
}

Md. Nazmul Huda (Main Author)

University of Malaya. Faculty of Engineering, Department of Civil Engineering, Kuala Lumpur, Malaysia.

nazmulhuda.128@siswa.um.edu.my

\section{Mohd Zamin Bin Jumat (Corresponding Author)}

University of Malaya. Faculty of Engineering, Department of Civil Engineering, Kuala Lumpur, Malaysia.

50603, Kuala Lumpur, Malaysia.

zamin@um.edu.my

\section{A. B. M. Saifull Islam}

University of Dammam. Department of Construction Engineering, College of Engineering, Dammam, Saudi Arabia. asislam@uod.edu.sa

\section{Mahmudur Rahman Soeb}

University of Malaya. Faculty of Engineering, Department of Civil Engineering, Kuala Lumpur, Malaysia. soeb@siswa.um.edu.my

Manuscript Code: 693

Date of Acceptance/Reception: 03.08.2016/06.10.2015

\section{Abstract}

Due to environmental issues, the use of waste materials in concrete is gaining popularity. Waste materials, such as oil palm shell (OPS) and palm oil clinker (POC) from the Malaysian palm oil industry are being used in various researches to produce lightweight concrete. Concrete containing only OPS shows more ductility and low compressive strength, while POC concrete shows less ductility but high compressive strength. The combination of OPS and POC may show improved compressive strength and ductility behavior. In this experimental study, the normal coarse aggregate is replaced by a mixture of OPS and POC aggregates in the lightweight concrete. The proportion of OPS and POC in the concrete mix varies from $40 \%$ to $70 \%$. The results indicate that if a mixture of OPS and POC aggregate in producing lightweight concrete, better performance regarding compressive strength and ductility can be achieved. Furthermore, through the utilization of waste materials, the proposed lightweight concrete will help to mitigate the negative impact on the environment.

Key words: Factory waste, OPS, POC, green concrete, lightweight material, engineering properties, ductility behavior

\section{Resumen}

Debido a las cuestiones ambientales, el uso de materiales de desecho en el hormigón está ganando popularidad. Los materiales de desecho, como la cascara de palma aceitera (OPS, en inglés) y el clinker de la palma aceitera (POC) de la industria del aceite de palma de Malasia están siendo utilizados en diversas investigaciones para producir cemento ligero. El hormigón que contenga sólo OPS muestra más ductilidad y baja resistencia a la compresión, mientras que el hormigón POC muestra menos ductilidad pero alta resistencia a la compresión. La combinación de la OPS y POC puede mostrar mejor comportamiento de ductilidad y resistencia a la compresión. En este estudio experimental, el agregado grueso normal es sustituido por una mezcla de agregados de OPS y POC en el hormigón ligero. La proporción de la OPS y POC en la mezcla varía de $40 \%$ a $70 \%$. Los resultados indican que si una mezcla de agregados de OPS y POC en la producción de hormigón ligero, mejora el rendimiento en cuanto a resistencia a la compresión y ductilidad. Además, mediante la utilización de materiales de desecho, el hormigón ligero propuesto ayudará a mitigar el impacto negativo en el medio ambiente.

Palabras clave: Residuos de fábrica, OPS, POC, hormigón verde, material ligero, propiedades de ingeniería, comportamiento de ductilidad.

\section{Introduction}

Nowadays, lightweight concrete is a popular choice in the construction sector. The use of lightweight concrete (LWC) has many advantages over normal weight concrete, such as a reduction in the size of the structural elements, increase in building height and a greater span-depth ratio for beams in pre-stressed concrete construction (Shannag, 2000). In designing a structural element, the compressive strength is desirable along with acceptable ductility under heavy loading to ensure adequate deflection (Aslam et al., 2014; Islam et al., 2013). Furthermore, it is widely acknowledged that concrete failure is sudden and brittle in nature in the case of diagonal tension (Cárdenas et al., 2010; Rahman et al., 2016). Satisfactory ductility is a crucial factor for reinforced concrete structures in high seismic areas. Because reinforced concrete has low ductility experiences many serious complications when subjected to compression and torsion. 
Currently, several researchers have worked on lightweight concrete using waste materials, as recycling the solid wastes from the agricultural and manufacturing industries is long overdue (Aldana \& Serpell, 2012; Jumaat et al., 2015; Mannan \& Ganapathy, 2001). Malaysia is the second largest palm oil producing country in the world producing more than half of the world's palm oil (Alengaram et al., 2016; Teo et al., 2006). At the same time, a huge quantity of solid waste is produced by the Malaysian palm oil factories. The residue of palm oil industry includes OPS and POC. Several investigations have shown that lightweight concrete with OPS or POC aggregate can be produced with a compressive strength ranging from 17 to $53 \mathrm{MPa}$ (Alengaram et al., 2016; Mohammed et al., 2014). The displacement ductility of lightweight concrete has rarely been studied in the earlier literature.

Therefore, the objective of this study is to produce lightweight concrete from a mixture of OPS and POC aggregates. Such lightweight concrete will be termed as palm shell and clinker concrete (PSCC). The compressive strength, modulus of elasticity, stress-strain correlation are investigated. Furthermore, the ductility behavior of PSCC has been studied. In addition, different mixing ratios of OPS and POC are examined to determine the best performance among the mixes regarding compressive strength and the ductility index of the critical compression members.

\section{Materials}

To carry out the investigation of compressive strength and ductility of PSCC concrete, the combination of OPS and POC as a coarse aggregate is considered in the concrete mixes. In the subsequent sections, the descriptions of the materials are provided.

\section{Cement}

In this study, ordinary Portland cement with a specific gravity of $3.14 \mathrm{~g} / \mathrm{cm} 3$ and fineness of $3510 \mathrm{~cm} 2 / \mathrm{g}$ was used as the binder material in the concrete. This cement was collected from a local Malaysian market. The compressive strengths of the cement were 34.2 and $45.9 \mathrm{MPa}$, at 7 and 28 days, respectively.

\section{Fine Aggregate}

Local mining sand with specific gravity, fineness modulus, water absorption and maximum grain size of 2.68, 2.65, $1.17 \%$ and $4.75 \mathrm{~mm}$, respectively, was selected as the fine aggregate in the concrete mix.

\section{Coarse Aggregate}

Two types of coarse aggregates were used in the concrete mix for this study, which was collected from the local palm oil factory in Malaysia as waste materials. Figure 1 shows the selected coarse aggregates for producing lightweight concrete. The OPS aggregate is shown in Figure 1 (A). It is worth mentioning that Shafigh et al. (2011) reported that OPS aggregate from crushing the larger original OPS aggregate might be an appropriate method to enhance the compressive strength of lightweight OPS concrete. After collecting the OPS from the local palm oil industry, it was washed and crushed using a stone-crushing machine in the laboratory. The flakiness of OPS decreases significantly upon crushing, which improves the performance of the coarse aggregate and yields higher compressive strength. Subsequently, crushed OPS aggregate was sieved using a $5 \mathrm{~mm}$ sieve to remove the aggregate less than $5 \mathrm{~mm}$ in size. Accordingly, the size of OPS aggregate used was $5 \mathrm{~mm}$ and larger. The mechanical properties of crushed OPS are given in Table 1.

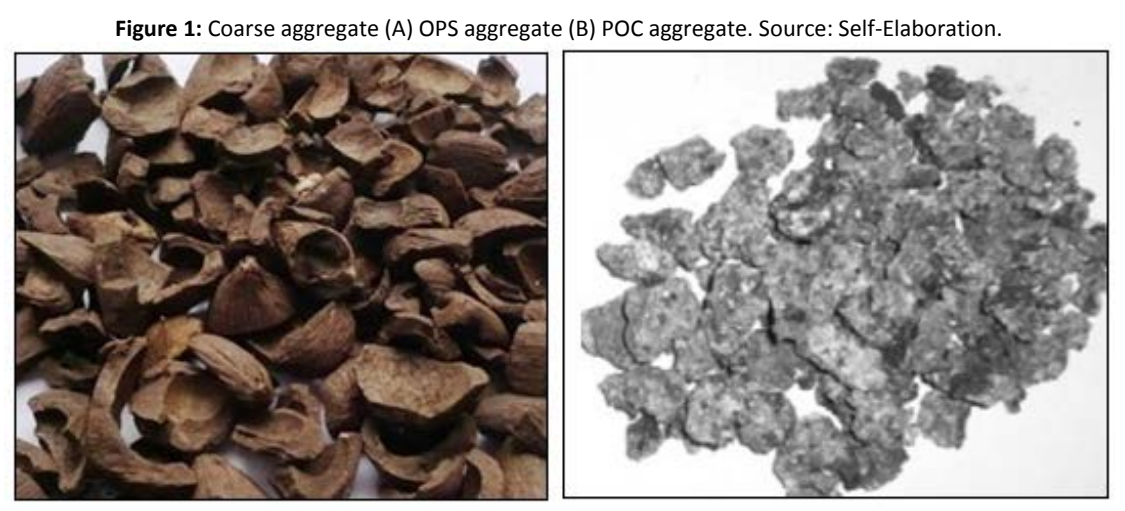


(A)

(B)

Another type of coarse aggregate, POC aggregate is presented in Figure 1 (B). This POC was also collected from the local palm oil industry in Malaysia. In a similar fashion to OPS, the clinker was crushed and sieved using a $5 \mathrm{~mm}$-sieve. As the larger size aggregate has a greater value under the abrasion test, POC retained on the $5 \mathrm{~mm}$ sieve was considered to be coarse aggregate. The mechanical properties of POC are also given in Table 1.

Table 1. Physical and mechanical properties of crushed OPS and POC aggregates.
\begin{tabular}{lll}
\multicolumn{4}{c}{ Source: Mannan \& Ganapathy, 2004; Mohammed et al., 2014. } \\
\cline { 2 - 3 } \multicolumn{1}{l}{ Physical and mechanical properties } & OPS & POC \\
\hline Aggregate size (mm) & $5-12.5$ & $5-12.5$ \\
Specific gravity (saturated surface dry) & 1.17 & 1.82 \\
Water absorption for 24 h (\%) & 23.3 & 4.35 \\
Aggregate abrasion value, Los Angeles (\%) & 4.8 & 27.09 \\
Bulk density (compacted) kg/m3 & 590 & 781.08 \\
Fineness modulus (F.M) & 6.24 & 6.75 \\
Flakiness index (\%) & 65.17 & - \\
Elongation index (\%) & 12.36 & - \\
Aggregate impact value (\%) & 7.86 & 25.36 \\
\hline
\end{tabular}

\section{Superplasticizer (SP)}

For this experimental program, Sika Viscocrete 2199, which was collected from Sika Kimia, was employed as the chloride free Superplasticizer, by EN 934-2, and mixed in the concrete at $2.0 \%$ of cement weight to facilitate the workability.

\section{Water}

Potable water, which was collected from the laboratory water supply system, was used for all the mixes, as well as for the purpose of curing.

\section{Mix Proportions}

By and large, the LWAC mix design is determined by trial mixes (Shetty, 2005). Most of the previous studies used 480 to $550 \mathrm{~kg} / \mathrm{m} 3$ cement with a water-cement ratio of 0.3 to 0.4 to obtain concrete with a compressive strength of 30 to $44 \mathrm{MPa}$. In this study, to obtain concrete with a compressive strength of $45 \mathrm{MPa}, 450 \mathrm{~kg} / \mathrm{m} 3$ cement content with a water-cement ratio of 0.35 was selected for the concrete mix. Therefore, unlike previous studies, this study designed the mixes with the less cement content to get high strength lightweight concrete (LWC) Four mixes were conducted in the laboratory to obtain grade 45 concrete with a high workability. To achieve workability, SP was added to all the mixes. Sieved local mining sand was selected as fine aggregate. Moreover, a mixture of OPS and POC was used as coarse aggregate in different proportions in the mixes. In mix TM-1, the total volume of coarse aggregate was divided into two parts: $70 \%$ for the OPS and $30 \%$ for the POC. The corresponding quantities in the volume of OPS and POC in the TM-2, TM-3 and TM-4 were 60\% \& 40\%; 50\% \& 50\%; and 40\% \& 60\%, respectively. The details of the concrete mixes with the proportions of ingredients are shown in Table 2.

Table 2. Concrete mix proportions in $\mathrm{kg} / \mathrm{m}^{3}$. Source: Self-Elaboration (2016).

\begin{tabular}{lllllllll}
\hline Mix ID & Cement & Water & $\begin{array}{l}\text { W/C } \\
\text { ratio }\end{array}$ & SP & Sand & $\begin{array}{l}\text { OPS } \\
\text { (\% by vol.) }\end{array}$ & $\begin{array}{l}\text { POC } \\
\text { (\% by vol.) }\end{array}$ & $\begin{array}{l}\text { Slump (mm) } \\
\text { (kg/m3) }\end{array}$ \\
\hline TM - 1 & 450 & 158 & 0.35 & $2 \%$ & 1013 & $248(70 \%)$ & $141(30 \%)$ & 180 \\
TM - & 450 & 158 & 0.35 & $2 \%$ & 1025 & $212(60 \%)$ & $187(40 \%)$ & 65 \\
TM - 3 & 450 & 158 & 0.35 & $2 \%$ & 1158 & $148(50 \%)$ & $195(50 \%)$ & 1991 \\
TM - & 450 & 158 & 0.35 & $2 \%$ & 1048 & $142(40 \%)$ & $281(60 \%)$ & 70 \\
\hline
\end{tabular}


In this study, the test matrices were divided into two parts to achieve the objectives. In carrying out the investigation, the first part involved the preparation of the test samples using a combination of OPS and POC, while the second part was the data collection from the experimental tests. Details of the experimental works are given in the following section.

\section{Preparation of test samples}

During preparation of the concrete mixing procedure, cement, sand, OPS and POC were blended into a pan mixer for 5 min. Subsequently, the mixture of SP and about $80 \%$ of the water were added into the pan mixture. After 5 minutes of mixing, the remaining $20 \%$ of the water was added to the pan mixture, and the mixing continued for a further 10 min. The concrete specimens were cast in steel molds, and the specimens were compacted using the vibration table. The casting of all the specimens followed BS 1881 (BS, 1983). The specimens were demolding after 24 hours and cured in water at $28 \pm 2^{\circ} \mathrm{C}$ until the test days. Three specimens from each category were prepared for obtaining the average value.

\section{Data collection}

Initially, the slump tests were carried out for the selected mixes. The compressive strengths of the specimens were determined on the 1st, 3rd, 7th and 28th day. In addition, the modulus of elasticity was measured on the 28th day. The tests were carried out according to BS 1881: Part 116 (BS, 1983) using a universal compression testing machine of $3000 \mathrm{KN}$ capacity with a rate of loading controller. For all the categories, the results of the testing of three respective randomly selected samples were averaged.

\section{Results and Discussion}

The mixture of POC and OPS gives a newly produced PSCC with competent concrete properties usable in construction industries. The results from the experimental program are critically discussed as follows.

\section{Compressive Strength}

Table 3 shows the 28 days compressive strength development for all the mixes. The test results show that if the percentage of OPS increases in the combination of coarse aggregate, the 28 days compressive strength decreases. Again, having a POC content of more than $50 \%$ also decreases the compressive strength. With the largest proportion of OPS content, TM-1 exhibits the lowest value for the 28-day compressive strength. TM-3, with a POC content of $50 \%$ in the mixture of coarse aggregate, shows the highest value for the 28-day compressive strength. In TM-4, the POC content was increased to $60 \%$, resulting in a $9 \%$ fall in the compressive strength from TM-3. This weakening can be attributed to the round and plain surface texture of OPS, which imparts poor bondage to the concrete if its presence is excessive. On the other hand, the POC aggregate, which is rough and porous, imparts strong bonding with the cement paste. Furthermore, if OPS and POC coarse aggregate are mixed in a $50 \%$ ratio (TM-3), the 28 -days compressive strength increases to $46.5 \mathrm{MPa}$, which is the maximum among all the mixes.

The cracking patterns of the cubes confirm the compressive failure, with the crack pattern producing a double pyramid shape after failure. From the crack pattern, it is immediately apparent that the stress within the cube is far from uniaxial. The compressive load induces lateral tensile strains due to Poisson's effect, and, hence, the lateral sides spall forming the double pyramid shape. One of the considerable advantages of the POC aggregate is that it has a rough surface, which helps to create stronger bonding with the cement paste. The crushing of the aggregate in the compressive test proves good bonding between cement paste and aggregate. However, POC aggregate is porous in nature, which enables some of the cementing material to enter the pores, that, eventually, decreases the overall bonding strength (Ahmmad et al 2014). This can be avoided by increasing the cement paste. Adding fine aggregate up to a certain level instead of cement can be an economical option. Therefore, an optimum mix is expected, which ensures better bonding and 28-day compressive strength. The mix, TM-3, refers to the optimum mix ratio in this study.

\begin{tabular}{ccccc}
\multicolumn{5}{c}{ Table 3. Development of the compressive strength of PSCC. Source: Self-Elaboration (2016). } \\
\hline & \multicolumn{5}{c}{ Compressive Strength (MPa) } \\
\cline { 2 - 5 } Mix ID & 1 day & 3 day & 7 day & 28 day \\
\hline TM-1 & 22.87 & 31.39 & 35.43 & 38.28 \\
TM-2 & 26.62 & 33.70 & 36.01 & 38.57 \\
TM-3 & 32.34 & 39.95 & 44.64 & 46.47 \\
TM-4 & 30.70 & 36.23 & 40.13 & 42.35 \\
\hline
\end{tabular}




\section{Stress-strain Behavior}

Figure 2 shows the stress-strain curves of all the tested samples containing different percentages of OPS and POC. Both vertical and lateral strains are plotted against the increase in the compressive load applied. The vertical displacement is shown in the positive X-axis and the lateral displacement in the negative X-axis in Figure 2. The stressstrain curves of the PSCC samples soften towards a rounded peak in the post-yield stage with a very slow dropping tendency after the post yield, which is mainly because the PSCC concrete has a good interlocking (Ahmmad et al., 2014) and bilinear ductile (Shafigh et al., 2012) stress-strain behavior. The experimental results show that the PSCC concrete specimen can undergo larger deformation before failure and that such a failure is ductile and gives warning of the impending failure similar to steel. For TM-3 and TM-4, the strains at maximum stress were measured in the range of 0.0028 and 0.0034 , respectively showing less value than that for TM- 1 and TM-2, which were 0.0035 and 0.004 , respectively; this is close to the range for lightweight concrete elements (Turatsinze \& Garros, 2008), 0.0260.003 . With the increase in the POC aggregate in the concrete, the strain at maximum stress exhibits a lower value, and, vice versa, with an increase in OPS aggregate. It is also observed that concrete with POC aggregate only shows brittle behavior with the maximum stress value whereas OPS concrete reveals the maximum ductile behavior with the minimum stress value. After combining the OPS and POC in the concrete, a higher stress value is found with moderate ductile behavior.

Figure 2. Stress-strain curves for vertical and lateral displacement. Source: Self-Elaboration. (2016).

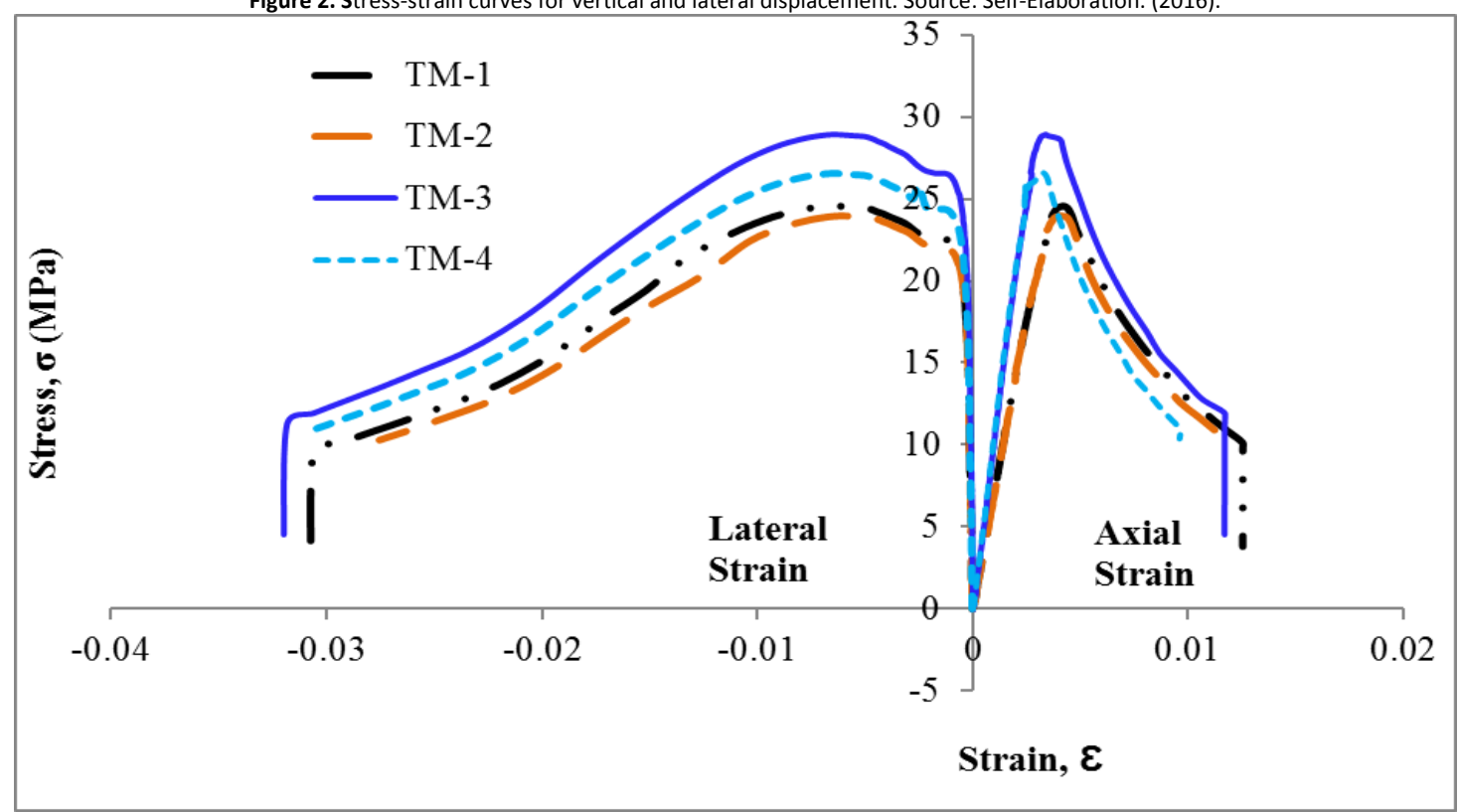

\section{Ductility Behavior}

The mechanical properties and ductility indices of PSCC obtained from the laboratory results are presented in Table 4. In addition, the concept of ductility indices is defined graphically in Figure 3. The ductility of any structural element is usually specified as the capacity of the structural element to undergo load still experiencing extra distortion beyond the maximum load stage' (Ahmmad et al., 2014). This definition is qualitative and to measure the displacement ductility of critical compression elements. The ratio of the area under the stress-strain curve up to $5 \varepsilon 0$ to the area up to $\varepsilon$ o for displacement is defined as the ductility index $(\mu)$, as shown in Figure 3 . The displacement ductility values stated in this study are the strain ductility of the compression-critical member. Here, $\varepsilon 0$ is the strain at peak stress (omax) for the concrete element. The evaluation of the structural parameters of the displacement ductility index is illustrated in Table 4 for the different mix ratios. Existing literature shows that POC concrete exhibits little ductility (Ahmmad et al., 2014). After mixing OPS with POC in this study, all the mixes show an adequate ductility index. TM-3 shows the maximum ductility among the mixes. 


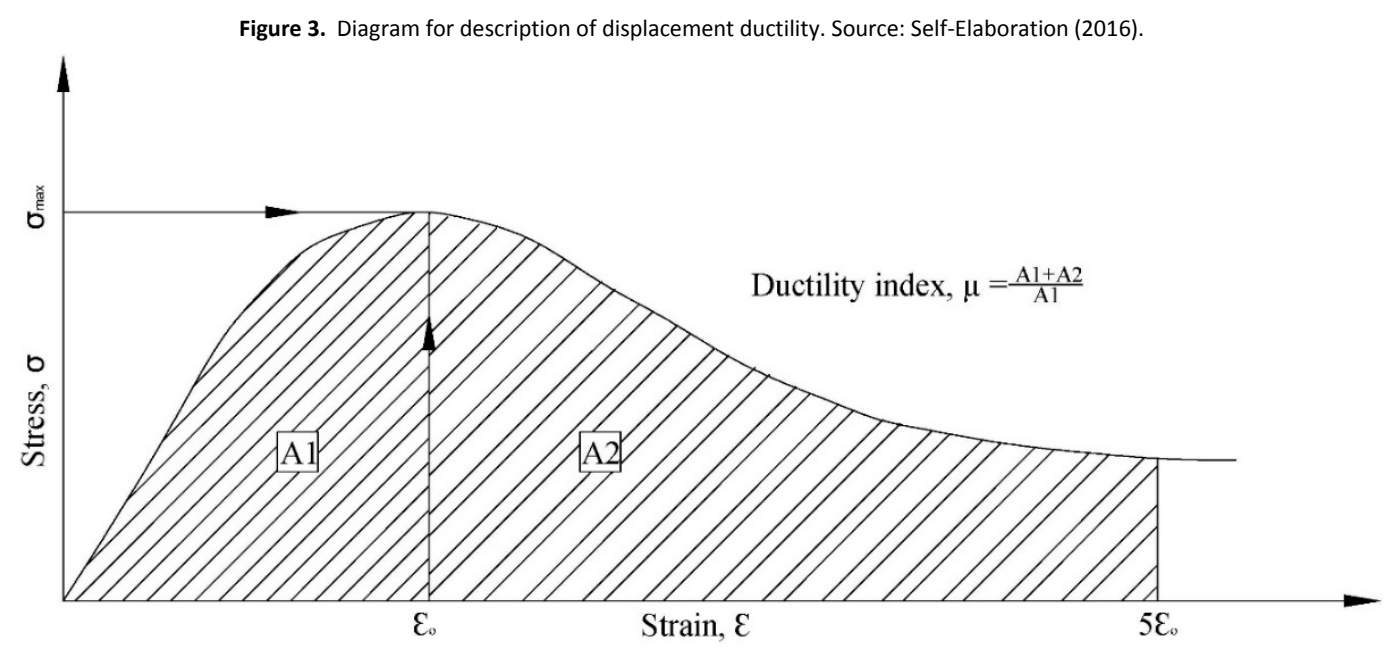

\begin{tabular}{lllll}
\multicolumn{5}{c}{ Table 4. Displacement ductility indices of PSCC for different mixture. Source: Self-Elaboration. } \\
\hline \multirow{2}{*}{ Mix ID } & Compressive & strength & Displacement ductility & \\
\cline { 2 - 5 } & (MPa) & Stress (MPa) & Strain & $\mu$ \\
\hline TM -1 & 38.28 & 24.00 & 0.00408 & 3.82 \\
TM -2 & 38.57 & 24.57 & 0.00422 & 3.67 \\
TM -3 & 46.47 & 28.92 & 0.00338 & 3.56 \\
TM - & 42.35 & 26.60 & 0.00324 & 3.26 \\
\hline
\end{tabular}

From the experimental study, following conclusions may be drawn:

1. The PSCC samples show ductile behavior. The ductility index decreases with the increase of porous POC aggregate content in the concrete mixes.

2. The strains at a maximum stress of the PSCC samples are in good agreement with the recent study of lightweight aggregate concrete.

3. PSCC can be produced with a 28-day compressive strength of $46 \mathrm{MPa}$, which is higher than the structural requirement of $15 \mathrm{MPa}$.

4. In this study, $450 \mathrm{~kg} / \mathrm{m} 3$ cement content was required to produce concrete having a compressive strength of 46 $\mathrm{MPa}$, which is the lowest among the recent studies.

\section{Acknowledgment}

The authors gratefully acknowledge the support given by University of Malaya (UM) for funding the work through Geran Penyelidikan Universiti Malaya (UMRG), RG 037A-15AET. 
Ahmmad, R., Jumaat, M., Bahri, S., Islam, A.B.M.S. (2014). Ductility performance of lightweight concrete element containing massive palm shell clinker. Construction and Building Materials, 63, 234-241. https://doi.org/10.1016/j.conbuildmat.2014.04.022

Aldana, J., Serpell, A. (2012). Topics and tendencies of construction and demolition waste: a meta-analysis. Revista de la construcción, 11 (2), 4-16. http://doi.org/10.4067/S0718-915X2012000200002

Alengaram, U.J., Mohottige, N.H.W., Wu, C., Jumaat, M.Z., Poh, Y.S., Wang, Z. (2016). Response of oil palm shell concrete slabs subjected to quasistatic and blast loads. Construction and Building Materials, 116, 391-402. http://dx.doi.org/10.1016/j.conbuildmat.2016.04.103

Aslam, F., Siddiqi, Z.A., Abbass, W., Hussain, R.R. (2014). Economical-Structural Performance of Steel Moment Resisting Building Frames Using the Section Variation Technique. Revista de la construcción, 13(1), 41-46. http://doi.org/10.4067/S0718-915X2014000100005

BS (1983). Testing Concrete. Method for determination of compressive strength of concrete cubes. London: British Standard Institution.

Cárdenas, M., Schanack, F., Ramos, O. (2010). Design, construction and testing of a composite glued timber-concrete structure to be used in bridges. Revista De La Construccion, 9(2), 63-75. http://doi.org/10.4067/S0718-915X2010000200007

Islam, A.B.M.S., Jumaat, M.Z., Hussain, R., Alam M.A. (2013). Incorporation of Rubber-steel Bearing Isolation in Multi-storey Building. Journal of Civil Engineering and Management, 19(sup1), S33-S49. http://doi.org/10.3846/13923730.2013.801904

Jumaat, M.Z., Alengaram, U.J., Ahmmad, R., Bahri, S., Islam, A.B.M.S. (2015). Characteristics of palm oil clinker as replacement for oil palm shell in lightweight concrete subjected to elevated temperature. Construction and Building Materials, 101 , 942-951. http://doi.org/10.1016/j.conbuildmat.2015.10.104

Mannan M., Ganapathy C. (2001). Mix design for oil palm shell concrete. Cement and concrete research, $31(9)$, $1323-1325$. http://doi.org/10.1016/S0008-8846(01)00585-3

Mannan M., Ganapathy C. (2004). Concrete from an agricultural waste-oil palm shell (OPS). Building and Environment, 39(4), 441-448. http://doi.org/10.1016/j.buildenv.2003.10.007

Mohammed, B.S., Foo, W., Abdullahi, M. (2014). Flexural strength of palm oil clinker concrete beams. Materials \& Design, 53, $325-331$. http://dx.doi.org/10.1016/j.matdes.2013.07.041

Rahman, M.M., Jumaat, M.Z., Hosen, M.A., Islam, A.B.M.S. (2016). Effect of adhesive replacement with cement mortar on NSM strengthened RC Beam. Revista de la Construcción, 15(1), 61-72. http://doi.org/10.4067/S0718-915X2016000100006.

Shafigh, P., Jumaat, M., Mahmud, H., Alengaram, U. (2011). A new method of producing high strength oil palm shell lightweight concrete. Materials \& Design, 32(10), 4839-4843. http://doi.org/10.1016/j.matdes.2011.06.015

Shafigh, P., Mahmud, H.B., Jumaat, M.Z. (2012). Oil palm shell lightweight concrete as a ductile material. Materials \& Design, 36, 650-654. http://doi.org/10.1016/j.matdes.2011.12.003

Shannag, M.J. (2000). High strength concrete containing natural pozzolan and silica fume. Cement and Concrete Composites, 22(6), 399-406. http://doi.org/10.1016/S0958-9465(00)00037-8

Shetty, M. (2005). Concrete technology theory and practice. 1rd Multicolor illustrative revised ed. S. Chand \& Company Ltd., New Delhi, India.

Teo, D., Mannan, M.A, Kurian, V.J. (2006). Structural concrete using oil palm shell (OPS) as lightweight aggregate. Turkish Journal of Engineering and Environmental Sciences, 30, 251-257.

Turatsinze, A., \& Garros, M. (2008). On the modulus of elasticity and strain capacity of self-compacting concrete incorporating rubber aggregates. Resources, conservation and recycling, 52(10), 1209-1215. http://doi.org/10.1016/j.resconrec.2008.06.012 